\title{
The Dualism of Tax Consultants' Roles in the Taxation System
}

\author{
Yenni Mangoting ${ }^{1 *}$, Retnaningtyas Widuri' ${ }^{2}$ Tonny Stephanus Eoh $^{3}$ \\ 1,2,3 Department of Tax Accounting, Petra Christian University \\ Jl. Siwalankerto 121-131, Surabaya 60236, Indonesia \\ *Corresponding author; Email: yenni@petra.ac.id
}

\begin{abstract}
The dualism of tax consultant's role as the agent of taxpayers and governments becomes a phenomenon in this research. Therefore, this research aims to understand the meaning of the dualism role of tax consultants in the taxation system. This study uses a qualitative approach to interpretive methods. The interpretive method assumes that reality does not stand alone but is constructed by the research subject. The method of data collection is done by interviewing two taxpayers and three tax consultants. The data analysis focused on the sentences and phrases that directly allude the researched phenomenon. The result of the research tells that there is an effort to balance the dualism of the role so that tax consultants can still protect the taxpayer's interests, while ensuring that their services do not harm the nation. The balance of the dualism of the role is reflected into four meanings, namely: taxpayer advisors, mediators of taxpayer and government conflicts, aligning taxpayer and government relations and controlling taxpayer compliance.
\end{abstract}

Keywords: Tax consultant; taxpayer; self-assessment.

\section{INTRODUCTION}

Tax consultants have a strategic position in the taxation system to support taxpayer compliance. This important role becomes more significant when the taxation system of a country is based on self-assessments that give full authority to taxpayers to carry out their own tax obligations, i.e. calculating, paying and reporting their tax due. Self-assessment requires taxpayers to perform tax obligations independently, voluntarily, and prioritize honesty. Independence, willingness, and honesty are difficult to achieve if the taxpayers are having difficulties in understanding the tax provisions which contain high complexity and are rapidly changing as the adaptations to the changes of business environments. [20] and [22] explained that the complexity and ambiguity of tax provisions are the obstacles in implementing selfassessment. This complexity and ambiguity will cause multiple interpretations of the articles in taxation provisions. For taxpayers, this condition will be detrimental because it causes high tax compliance costs and mistakes in calculating the tax due which then leads to sanctions and administrative fines.

To overcome the difficulties in interpreting tax provisions that will provide risks for the emergence of sanctions and tax administration fines, the taxpayers use the role of a tax consultant. [5] described that the main reason for taxpayers to use tax consultant services is to help them in interpreting tax provisions which are considered complicated and difficult to interpret. Furthermore $[8$, $25,35]$ explained that taxpayers need the competency of tax consultants who are considered to be capable of solving the problem of uncertainty caused by the complexity of tax provisions.

The important role of tax consultants in the taxation system becomes complicated when the tax authorities make tax consultants into partners to support quality and increase tax compliance. On a different side, the existence of a tax consultant can be influenced by the motivation of taxpayers to fulfill their tax obligations [32], who generally have the perception that tax is a burden that should be minimized. With this perception, taxpayers can actually use the competency of tax consultants to do tax avoidance [5]. The contradictory objectives of taxpayers who want to maximize profits and the government's goal of maximizing the state revenues have placed tax consultants in a dilemma position.

The explanation above shows the dualism of the role of tax consultants in the taxation system. On one hand, the tax consultant is an agent of compliance that becomes the representative of the governments in building tax compliance. On the other hand, a tax consultant is an agent of the client. As an agent of clients, it is not uncommon for tax consultants to actually weaken taxpayer compliance through aggressive tax avoidance. The 
dualism of the role of the tax consultant brings a hidden meaning to how tax consultants actually interpret their roles simultaneously. The first role is as a representative of the governments to enforce tax compliance, but at the same time, be a part of the taxpayers to carry out their tax compliance as a client.

How tax consultants interpret that dualism role will be influenced by attitudes, motivations, values, personality traits, and the interactions between the tax consultant with the environment [1, 2]. The dualism role of a tax consultant as a research object is part of a social reality that is formed from time to time through the process of communication, interaction with the environment, and part of the past events [7]. Therefore, this study uses an interpretive approach to answer the research questions on how tax consultants interpret the dualism role in the taxation system. The importance of exploring the role of tax consultants will help the government in repositioning the role of tax consultants in the taxation system in Indonesia

\section{RESEARCH METHOD}

Science is not just meant to test, to predict or to explain a theory. Science seeks to solve real problems that occur through interaction in the social world that uses humans as subjects and objects. Therefore, it is necessary to look at and examine a phenomenon from another perspective by involving individuals and perceptions to understand the reality or originality which is actually not dependent on the representation of the population, which is the focus of qualitative research [33].

This study uses qualitative interpretive methods. It focuses on understanding the way humans interpret their social life, and how humans express their understanding through language, sound, parables, personal styles, and social rituals [7]. Interpretive research will produce meaning, obtained through a process of subjective interpretation expressed by each individual, which in the context of this study are two taxpayers and four tax consultants [40]

The method of data collection is done through interviews with research subjects, namely two taxpayers and four tax consultants. The data analysis in this study focuses on making interpretations to get the meanings inherent in the interview text in order to get overall meaning. The analysis is focused on sentences and phrases that directly discuss the phenomenon observed. The stages of data analysis in this study are: 1 ) conducting the interpretation of the first stage by labeling the results of the interview. In the labeling process, the researcher marks the important statements from the research subjects, 2) interpreting the second stage by giving a description of the meaning of each research subjects to a phenomenon, 3) interpret the stage three. At this stage, the researcher associates one meaning with another to get the final meaning about the phenomenon of how tax consultants interpret the dualism of their role in the taxation system [40].

\section{RESULT AND DISCUSSION}

One of the many reasons why taxpayers use tax consultant services is because of its efficiency in terms of time and cost [34]. However, from the results of the interviews with the research subjects, namely taxpayers Joko and Damara, it is known that the main consideration in using tax consultant services because of the lack of mastery in the field of taxation. For the subjects of this study, the tax provisions are considered difficult and confusing, which makes them need a tax consultant who can help them to settle their tax obligations, as stated below:

"I hired tax consultants because honestly [I don't really understand] tax regulations. I think tax regulation is quite [complex, so it is difficult to understand]"

"Generally they want to pay taxes, at least taxpayers used consultants so that they know the tax aspects. Whether I want to pay or not, it is my own business. [Compared to the situation where I do not know anything if I do not hire a consultant]"

The words in parentheses of each interview result with the research subjects are a form of labeling, which is done to get the client's important statements as the object of meaning at the next stage of interpretation. Then, the interpretation of the second stage is done by giving meaning to the expressions of the research subject that were found on the words in the parenthesis.

The statement above reveals the limitations of taxpayers in understanding tax provisions, which are considered complex and make it difficult to understand. However, the desire to obey did not decrease because of the existence of tax consultants who could help settle their tax obligations. The choice of using a tax consultant service is also motivated by their belief, that a tax consultant can bridge the information barriers regarding tax provisions, compared to meeting and utilizing the Account Representatives, namely tax officers provided at the Tax Office to overcome taxpayer difficulties.

The complexity of tax provisions faced by taxpayers is a fact of obstacles in the field that might disrupt the enforcement of taxpayer com- 
pliance. These obstacles are basically not in accordance with the principle of fairness in tax collection, which requires a simplification in tax provisions. Simplification of tax provisions becomes absolute because taxpayers run a tax system based on Self-Assessment. The Self-Assessment that relies on volunteerism, independence, and honesty of taxpayers in fulfilling the obligation to calculate, pay, and report their tax due will be difficult to achieve if the taxpayer does not understand the provisions of the taxation itself.

The lack of understanding about the tax provisions actually creates a taxpayer's resistance attitude. They act passively so that they submit all settlement of tax obligations to the tax consultant. It can be seen from the statement of the research subject namely Andika, who is a tax consultant:

"[Tax consultants must play a role], because taxpayers would actually follow what the tax consultant said. For example, the tax consultant will suggest the tax costs and asks whether the taxpayers agree with that number or not. If the taxpayer approves, [the tax consultant will adjust to the tax calculation "]

Andika's statement above is part of the experience when dealing with a passive taxpayer. If the taxpayer is being passive, the tax consultant can direct the behavior of taxpayer compliance. Apart from being clueless and considering that the tax provisions are complicated, the tax consultants are asked to regulate the tax payments based on the taxpayer's ability to pay, not based on the records or bookkeeping that report on the economic ability of taxpayers. The attitude of taxpayers who tend to be apathetic as in the results of the interviews above can affect the behavior of the tax consultant itself.

[4] realized that the characteristics and motivation of taxpayers as clients become the tax consultant's considerations of advocacy and decision making.

This complexity issue does not only happen in Indonesia but also in other countries, like Malaysia. In order to overcome the problems in this complexity, tax authorities in Malaysia or the Inland Revenue Board of Malaysia (IRBM) were asked to formulate the standard and the simple taxation provisions to reduce ambiguity in order to improve the quality of voluntary compliance [14]. The complexity of tax provisions can also make it difficult for tax authorities because it can disrupt the consistency of the operationalization of tax provisions and different law enforcement efforts between them [13].

Aside from helping to settle taxpayers' tax obligations as clients, there is a tendency that taxpayers might use the tax consultants to conduct aggressive tax avoidance. One of the research subjects, Chaca, as a tax consultant provides the following information:

"There are always those who persuade to [help taxpayers pay taxes based on the targets that are specified in advance], but my answer is, "I only have one heart, no backup" principle of a tax consultant who approves the client's wishes is "[anything that makes you happy]"

The above statement shows the existence of aggressive behavior that is shown not only by taxpayers but also by tax consultants. Both of them cannot avoid having economic or transactional relationships. Economic dependence is indeed an obstacle to enforce the attitude of the independence of tax consultants to be able to reject the wishes of clients who are not in accordance with the tax provisions and ethics codes of tax consultants and fulfill the wishes of clients. If the motivation that underlies the attitude of tax compliance is the principle of "tax is the cost for doing business", then the desire of the taxpayer to disobey will never be gone. Thus, to actualize this urge, the taxpayers can use the tax consultant's expertise and competence to carry out tax avoidance. [4] explained that for certain clients, tax consultants can consider the risks in order to use the ambiguity in tax provisions to create tax avoidance strategies.

Personal interest conflicts and professionalism as a tax consultant sometimes become the obstacles for tax consultants in doing the client's duties in accordance with the professional code of ethics. That is also stated by Widi, a tax consultant, as can be seen below:

"When I am accepting a request to do the client's duties, I asked myself, [is it wrong to cheat] work like this?"

[9] and [10] explained that tax consultants have a unique position because they work for two bosses with different behalf, i.e. the government and taxpayers. In line with the above opinion, [30] also admitted that the dual role of tax consultants, who on the one hand are the allies of taxpayers, but on the different side, they are the government's allies, who are obliged to fulfill the client's tax obligations in accordance with the tax provisions.

It is not easy for a tax consultant to balance their position between the taxpayer's behalf as clients and the government as a tax authority. [39] stated that the dual role of the tax consultant is difficult to be avoided. The dilemma of the intermediary position with different responsibilities leads to strong pressure, so it tends to place tax 
consultants in a difficult position to act based on the objectives expected by both parties [6,34]. Not only in Indonesia, the Australian tax authority, named Australian Tax Officers (ATO), realizes that tax consultants do not only function to provide advocacy and prepare client's tax reporting, but also provide a risk management service in order to minimize the tax payments [4,24].

As a tax consultant, Chacha knows the behavior of a tax consultant who sometimes acts out of their duties and responsibilities, as it is said in the following statement:

"[More people are using tax planning by using the weaknesses of tax provisions]. But it does not rule out the possibility for tax consultants to become a wholesale consultant, by making financial reports while calculating their taxes, in order to make it easier to regulate the amount of the tax due".

The above statement is an affirmation that a client preference is that taxpayers become one of the factors that can influence ethical decision making. Many studies explain that when tax provisions have a double meaning, there is a risk of tax audits, low tax sanctions, high taxable income, then there is a tendency for tax consultants to consider preparing an aggressive tax reporting [25]. Even though tax consultants in their assignments provide objective advocacy to clients, it is possible that tax consultants can implement aggressive tax avoidance strategies when dealing with clients who are economically capable of paying large amounts of their services [4].

Not all tax consultants fulfill the behalf of taxpayers, even with a large fee, as in the statement of Chaca's below:

"He used a tax consultant before using our services. Its profit is huge. [But the fact is that this company has downplayed their taxes]. And it does not make sense, for example, it does not have stocks. [Finally, as a tax consultant, I resigned myself from this assignment] with the excuse that the taxpayer is not open to his tax matters."

As a tax consultant, Chaca realizes that her work can give her economic benefits easily if she wants to fulfill the client's behalf, even if it takes a high risk to do it. Many taxpayers are willing to pay the tax consultants who can do aggressive tax avoidance with a low risk of detection. But for Chaca, high pay is not comparable with future risks if the aggressive tax avoidance is detected by the tax authorities.

This uncertainty can have an impact on the behavior of taxpayer compliance. Taxpayers can make a reason that their negligence in fulfilling tax obligations is caused by the difficulties in understanding taxation provisions. The uncertainty of the complexity of tax provisions can also change the character of the taxpayer's risk. [14] explained that the complexity of taxation provisions would confuse taxpayers, even they could intentionally disobey because it was intended to exploit these difficulties. Taxpayers who like to take a risk will use the conditions of this uncertainty to increase or decrease their taxable income, while those who do not, the uncertainty becomes a loss, so they strive to minimize the impact by seeking information on tax provisions as much as possible $[3,15]$.

For taxpayers, this uncertainty must end by involving the role of a tax consultant. The consequence is the cost of tax compliance with the existence of a tax consultant becomes higher. However, the choice to use tax consultant services to settle the tax obligations becomes a priority for taxpayers in anticipating the consequences of future sanctions due to errors in fulfilling tax obligations [18]. The role of a tax consultant is believed to be able to facilitate the settlement of taxpayer problems, as they have competent competences in solving the complex problem of tax provisions that can disrupt the performance of tax compliance.

[8] in his research proved that there is a significant effect on the increase of taxpayer compliance with the role of a tax consultant. In fact, the central role of tax consultants is not only from the perspective of taxpayers but also by tax authorities [37]. [27] admitted that even though a tax consultant is not a party who directly involved in the relations between taxpayers and tax authorities, its existence actually has the capacity as a facilitator who provides the taxpayers with advocacy and becomes a taxpayer's challenge in interacting with tax authorities.

\section{Tax Consultants are Mediators of Taxpayer Conflicts and Tax Authorities}

Conflict in the relationship between taxpayers and tax authorities is not a coincidence. [11] underlined the disharmony between taxpayers and tax authorities. The disharmony of this relationship is underscored by the different perceptions regarding tax payments. Taxpayers, as rational beings, assume that tax payments are an additional burden that can reduce economic capacity. Moreover, the tax payment does not get the compensation that can be directly appointed. Meanwhile, the tax authorities get the legitimacy to secure state revenues by increasing taxpayer compliance. 
[31] described the ambiguity of tax provisions, injustice in law enforcement, and social exchange can be the factors that cause conflict so that taxpayer factors justify aggressive tax avoidance. In fact, the leaking of state finances problem which is caused by the corruption done by public placeman can lead to a conflict of dilemmas that have an impact on taxpayer compliance [26]. Taxpayers become less interested in paying taxes because the state does not provide direct incentives for taxes that have been paid. In fact, what might happen is that taxpayers will hesitate to pay taxes. The conflict which has an impact on the behavior of taxpayer compliance has been debated in many studies which then led to some compliance modeling, especially when the government uses its legitimacy to give sanctions on taxpayers.

An open conflict also happens when complex tax provisions create a different interpretation between taxpayers and tax authorities, which then leads to disputes that must be solved in a court [36]. Therefore, these conflicts need the role of intermediaries, i.e. tax consultants. The phenomenon illustrated in the analysis of interview data with research subjects shows that the tax consultant can act as a mediator. It is difficult for the intermediaries to be in the uncertainty because of the difficulty in understanding the provisions of taxation and mediators when taxpayers want to act aggressively in doing the tax obligations by exposing legal risks in the future.

\section{Tax Consultants are the Relations Synchro- nizer of Taxpayers and Tax Authorities}

[9] and [10] explained that tax consultants have a unique position as they work for two clients, i.e. government or tax authorities, and taxpayers with different objectives and interests. This position can put them in a difficult situation to balance themselves.

The dilemma in the position as an intermediary that brings different interests and objectives causes the tax consultant to get strong pressure from both sides [6].

[38] also gives close attention to the dualism in the tax consulting profession, that tax consultant is a taxpayer advisor who helps to fulfill the tax obligations based on its provisions. On the other hand, tax consultant is a profession which is regulated by the Ministry of Finance and it is has a professional bond so that they have ethical and legal responsibilities given to them. It is not easy for tax consultants to be neutral when they are in the middle of two different interests. As clients, taxpayers sometimes want the aggressive tax avoidance actions that can provide tax savings with low risk [34], but on the other hand, they are the representative of the governments with the mission to improve the tax compliance. This phenomenon will place the tax consultant in a dilemma position, as [30] explained that the dilemma will be faced by tax consultants because on the one hand, they are the allies of taxpayers but on the other hand, they are the allies of the government in increasing the state revenues through tax compliance

In maintaining the function of a tax consultant as the agent of compliance, they must be bounded by the code of ethics as a guide to fulfilling the client's request. The code of ethics is a moral code that would guide the tax consultants in thinking, behaving and acting. [12] illustrated that an organization which has accustomed itself to work and make decisions based on the professional code of ethics will influence the ethical behavior of the tax consultants themselves.

Although tax consultants have sufficient competence in doing client's request through mastery of taxation provisions, it does not mean that they take aggressive actions to side with the interests of clients. The engagement with an ethics code would be able to control the behavior of tax consultants to do the taxpayer duties according to taxation provisions. This is proven in the research of [10] which explained the tendency of tax consultant behavior in New Zealand to act conservatively in giving advice to clients. They understand that taxpayers will ask for their responsibilities in the future if their aggressive actions endanger the client's business. In addition, [10] explained that tax consultants in New Zealand would provide complete advice and explanations to taxpayers to avoid future claims. Although tax consultants are aware of the dualism of their role, they are still required to balance their position between the two parties, so that there will be harmony in realizing the goals of each party.

According to [29], tax consultants are actually considered as independent parties and can be a tool to harmonize the different interests between taxpayers and tax authorities. That statement is relevant when the government keeps striving to improve the quality of their relations with taxpayers so that taxpayers can change their perceptions that the tax is a burden and having no contravention on their tax payments. These perceptions and views will be changed by the government in order to create a good relationship between the two. However, this effort would be difficult to be done without an independent party who can harmonize the interests of both. Therefore, [29] argued that it is necessary to present the role of tax consultants in facilitating and bridging dialogue bet- 
ween taxpayers and the government to create common perceptions so that each has the confidence to create a quality relationship.

\section{Tax Consultant is a Taxpayer Compliance Controller}

Taxes can change the behavior of taxpayers to be obedient or not. Like some studies, [21] identified several taxpayer characteristics called "legal" tax evaders, tax evader by fraud, evader by simple omission, and abusive planner (illegal avoidance) legitimate planner (legal avoidance), simple compliant taxpayer, Under-compliant taxpayer, and Illegitimate withholder. The research above explains that not all taxpayers are compliant to do their obligation to pay taxes. Obedient and disobedient behaviors can also be identified from the character of the tax consultant. [32] described the characterristics of tax professionals, i.e. creative consultants, honest consultants, and cautious consultant, and Machiavellian. The description of the character of taxpayers and tax consultants above indicates that there is a motivation in doing tax avoidance, whether it is exploiting or opposing the taxation provisions.

[37] explained that the behavior of obedient or disobedient taxpayers can also be influenced by the role of the tax consultant. Tax consultants do not only act as intermediaries between taxpayers and tax authorities but more like influencing the taxpayer compliance behavior. However, there are also taxpayers who exploit the weaknesses of tax provisions aggressively, which then makes the state lose revenue and causes damage to the taxation system [19].

Although it does not explicitly say that tax consultants conduct aggressive tax avoidance, [24] believed that the taxpayer's dominance can direct them to do so. The study results of [28] also believed that the role of tax consultants as an intermediary has a major influence on the behavior of taxpayer compliance. According to [19], economic interests are fundamental issues that still become obstacles for tax consultants to maintain their independence. It also becomes a motivation for taxpayers in making both parties dare to act aggressively in tax avoidance. Economic interest is a pressure, not only for taxpayer, in particular the multinational companies that want to earn profits as much as possible for the stakeholders interest, but also for tax consultants, aside from receiving the benefits from the success of tax saving also as an effort to maintain their existence in the competitive service market.

This condition was realized by [23] that tax consultants play a role in overcoming the taxpa- yer's information barriers and helping in completing tax calculations. However, tax consultants also have the expertise to take advantage of noncompliance opportunities. In situations where tax provisions do not contain ambiguity, the tax consultants are more likely to take positions as law enforcers and choose to act conservatively in doing tax provisions. However, according to [17], when the tax provisions are complex and containing ambiguity, tax consultants can actually exploit the provisions of the tax law to do an aggressive tax avoidance, even if it against the taxation provisions.

Taxpayers who want to do tax avoidance will use the services of a tax consultant because they are considered to have the professional ability in understanding the weaknesses of tax provisions [5]. Even though a tax consultant is an agent of compliance, the taxpayer's pressure would still make it difficult for tax consultants to do the duties independently. Especially when the pressure is related to the financial problem of the tax consultant. Therefore, it is difficult to expect the freedom of tax consultants to do the duties in a neutral way, and there will be a partiality position on one of the interests. As stated by [8], statistically, a tax consultant has a significant influence on tax compliance.

The explanation above concludes that the dualism position of tax consultants as both government and taxpayer agents are not balanced. Thus, from this explanation, it can be said that tax consultants act as controllers of taxpayer's compliance and non-compliance behavior. The difficulty of a tax consultant to take a balanced position in having two roles as the representative of the governments or an agent of compliance that will help to increase taxpayer compliance [16] and as an agent of the taxpayers. Tax consultants' economic dependence on taxpayers is an obstacle to do their role as an agent of compliance so that there is a tendency for tax consultants to approve the taxpayer's desire to do aggressive tax avoidance.

\section{CONCLUSION}

Tax consultants consider their role as taxpayer advisors. This interpretation is formed when taxpayers have difficulty in implementing tax obligations because of the lack of understanding of the taxation provisions and worries about getting sanctions in the future. Trust is the key for taxpayers to have tax consultants as parties who are considered capable of completing tax obligations. Taxpayers choose to entrust their settlement of tax obligations to get comfort, convenience and time efficiency in doing their company's operationa- 
lization. However, tax consultants are also aware that the formation of a taxpayer's perception that tax is a burden will give them an opportunity to provide aggressive advice for them.

Tax consultants interpret their role as mediators of conflicts with the government or tax authorities. Conflicts arise because the taxpayers are in a tax system that is not conducive for doing their tax obligations based on Self-Assessment. The complicated tax provisions that make it difficult to understand and the lack of socialization create the resistance of taxpayers to implement tax compliance. Then, conflicts also happen when the benefits of tax payments have not been felt through public services or the high number of corruption cases of public placeman. Besides, conflict is very likely to happen in an engagement relationship, including the relationship between the taxpayers and tax authorities. While in the case of tax audits, objections and appeals, the tax consultant will play an important role as a mediator.

Tax consultants interpret their roles as a synchronizer of the relationship between taxpayer and tax authorities through a code of ethics. The code of ethics is the basic foundation of tax consultants in doing taxpayer duties. Different interests between taxpayers who seek to minimize tax payments and tax consultant responsibilities as government agents to build awareness of taxpayer compliance. In synchronizing this dualism of the role, the tax consultant must internalize the rules of the game set out in the code of ethics. Although the relationship between tax consultants and taxpayers is transactional, the tax consultants are required to work by upholding the professional code of ethics. Tax consultants still declare partiality to taxpayers within the corridor of tax law, so that it would not interfere with the interests of the tax authorities whose duty is to maintain tax revenues.

Tax consultants interpret their role as controlling taxpayer behavior. The tax provisions that contain ambiguity can be used as loopholes to create an aggressive tax avoidance strategy. Taxpayers who consider that tax is a burden can communicate this desire to competent tax consultants in order to use that flaw as a tax avoidance strategy.

This research is a reference for the tax authorities to formulate policies in order to re-regulate the central position of tax consultants in the taxation system. In addition, the tax authority is expected to be able to formulate simpler tax provisions and not containing ambiguity, to minimize the possibility for tax consultants to exploit these flaws as a tool to do the tax avoidance.

\section{REFERENCES}

[1] Andon, P., Free, C. and Scard, B. (2015). Pathways to accountant fraud: Australian evidence and analysis. Accounting Research Journal, 28(1), 10-44.

[2] Azwar, S., Sikap Manusia, Teori dan Pengukurannya, Pustaka Pelajar., Yogyakarta, 1995.

[3] Beck, P.J., J.S. David, and W.-O. Jung. 1991. Experimental Evidence on Taxpayer Reporting under Uncertainty. The Accounting Review, 66(3), 535-558.

[4] Bobek, D. D., Hageman, A. M. and Hatfield, R. C. (2010). The role of client advocacy in the development of tax professionals' advice. Journal of the American Taxation Association, 32(1), 25-51.

[5] Carley, K.M. and D.T. Maxwell., Understanding Taxpayer Behavior and Assessing Potential IRS Interventions Using Multiagent Dynamic-Network Simulation. Proceedings of the 2006 Internal Revenue Service Research Conference, Washington, DC, 2006, 93-106.

[6] Cox, S.R. and R.R. Radtke. 2015. The Effects of Multiple Accountability Pressure on Tax Return Preparation Decision. Advances in Taxation, 12, 35-50.

[7] Daymon, C. and I. Holloway., Metode-Metode Riset Kualitatif dalam Public Relations dan Marketing Communication, Bentang., Yogyakarta, 2008.

[8] Devos, K. (2012). The impact of tax professionals upon the compliance behaviour of Australian individual taxpayers. Revenue Law Journal, 22(1), 31.

[9] Fogarty, T. and A. Jones, D. 2014. Between a rock and a hard place: How tax practitioners straddle client advocacy and professional responsibilities. Qualitative Research in Accounting \& Management, 11(4), 286-316.

[10] Gupta, R. (2015). Relational impact of tax practitioners' behavioural interaction and service satisfaction: Evidence from New Zealand. eJournal of Tax Research, 13(1), 76-107.

[11] Gutman, H.L. 2012. The Role of the Tax Advisor in the Changing World of Global Tax Administration: The 2012 Erwin N. Griswold Lecture Before the American College of Tax Counsel, The Tax Lawyer, 65(3), 461-476.

[12] Hageman, A.M. and D.G. Fisher. 2016. The Influence of Client Attributes and Organizational Climate on Tax Professionals. Research on Professional Responsibility and Ethics in Accounting, 20, 31-66.

[13] Holtzman, Y. (2007). Challenges in achieving transparency, simplicity and administering of the United States tax code. Journal of management development, 26(5), 418-427. 
[14] Isa, K. (2014). Tax complexities in the Malaysian corporate tax system: minimise to maximise. International Journal of Law and Management, 56(1), 50-65.

[15] Kaplow, L. (1998). Accuracy, Complexity, and the Income Tax. The Journal of Law, Economics, and Organization, 14(1), 61-83.

[16] Killian, S. and Doyle, E. (2004). Tax aggression among tax professionals: the case of South Africa. Journal of Accounting, Ethics and Public Policy, 4(3), 159-189.

[17] Klepper, S., Mazur, M. and Nagin, D. (1991). Expert intermediaries and legal compliance: The case of tax preparers. The Journal of Law and Economics, 34(1), 205-229.

[18] Kwon, M.M. 2014. Dysfuction Junction: Reasonable Cause and Good Faith Reliance on Tax Advisor with Conflict Interest., The Tax Lawyer, 67(3), 403-450.

[19] Larin, G. N., Duong, R. and Jacques, M. (2008). Policy Forum: Responses to Aggressive Tax Planning-A Study Framework. Canadian Tax Journal, 56(1), 143-159.

[20] Martins, A. (2013). Complexity in the tax law and reported earnings: cost deduction in the Portuguese fiscal system. Journal of Financial Reporting \& Accounting, 11(2), 166-178.

[21] Mitu, N. E. 2016. Taxpayer behaviour: typologies and influence factors. Revista de Științe Politice. Revue des Sciences Politiques (49), 77 87.

[22] Mulligan, E. and L. Oats. 2016. Tax and Performance Measurement: An Inside Story., Advances in Taxation, 23, 59-85.

[23] Murphy, K. and Y. Sakurai., Aggressive Tax Planning: Diffrentiating Those Playing The Game From Those Who Don't T, Centre for Tax System Integrity, Research School of Social [22]Sciences, Australian National University Australia, 2001.

[24] Niemirowski, P. and Wearing, A. J. (2003). Taxation agents and taxpayer compliance. Journal of Australian Taxation, 6(2), 166.

[25] Nienaber, S. G. 2010. Factors that could influence the ethical behaviour of tax professionals. Meditari Accountancy Research, 18(1), 33-46.

[26] Nkundabanyanga, S. K., Mvura, P., Nyamuyonjo, D., Opiso, J. and Nakabuye, Z. (2017). Tax compliance in a developing country: Understanding taxpayers' compliance decision by their perceptions. Journal of Economic Studies, 44(6), 931-957.
[27] OECD. 2007. The Enhanced Relationship, Working Paper 6, OECD Tax Intermediaries Study, 1-31.

[28] OECD., Study into The Role of Tax Intermediaries, 2008.

[29] Owens, J. 2012. Tax Administrators, Taxpayers and Their Advisors: Can the Dynamics of the Relationship Be Changed, Bulletin For International Taxation, 516-518.

[30] Pickhardt, M. and Prinz, A. (2014). Behavioral dynamics of tax evasion-A survey. Journal of Economic Psychology, 40, 1-19.

[31] Pui Yee, C., Moorthy, K. and Choo Keng Soon, W. (2017). Taxpayers' perceptions on tax evasion behaviour: an empirical study in Malaysia. International Journal of Law and Management, 59(3), 413-429.

[32] Sakurai, Y. and V. Braithwaite. 2001. Taxpayers' Perception of The Ideal Tax Adviser: Playing Safe or Saving Dollars Working Paper, 5, 1-32.

[33] Somantri, G.R. 2005. Memahami Metode Kualitatif, Makara, Sosial Humaniora., 9(2), 57-65.

[34] Stephenson, T., G. Fleischman, and M. Peterson. 2017. Demand for Tax Preparation Services: An Exploratory Examination of Client Versus Tax-Preparer Expectation Gaps. Advances in Taxation, 24, 199-231.

[35] Tan, L.M., Types of Advice from Taxpayers: A Preliminary Examination of Taxpayers's Preference, Discussion Paper Series, Department of Accountancy and Business Law, Massey University Palmerston North, 1998, 4-29.

[36] Thuronyi, V. and I. Espejo., How Can Excessive Volume of Tax Disputes Be Dealt With? Legal Department IMF, 2013, 1-63.

[37] Tomasic, R. and B. Pentony. 1990. Defining Acceptable Tax Conduct: The Role of Professional Advisers in Tax Compliance, Criminology Research Council, 1-63.

[38] Waples, E. and Darayseh, M. (2009). Ethics and Tax Education: A Change in Focus Is Needed. American Journal of Business Education, 2(6), 1-6.

[39] Wolfman, B. and J.P. Holden. 1982. Ethical Problems in Federal Tax Practice. Harvard Law Review, 95(8), 1995-2009.

[40] Wuisman, J.J.J.M, Teori dan Praktek: Memperoleh Kembali Kenyataan Supaya Memperoleh Masa Depan, Yayasan Pusaka Obor., Jakarta, 2012. 